\title{
Pollination and Breeding system of Ranunuclus japonicus Thunb. in Japan
}

\author{
(Penyerbukan dan system reproduksi Ranunuculus japonicus Thunb. di Jepang)
}

\section{Syamsuardi}

Jurusan Biologi, Fakultas MIPA, Universitas Andalas, Kampus Limau Manis Padang 25163

E-mail: syamsu.ardi@telkom.net

\begin{abstract}
Abstrak
Penelitian tentang penyerbukan dan sistem reproduksi Ranunculus japonicus telah dilakukan di kebun botani Universitas Osaka City, Katano, Osaka, Japan. Hasil penelitian menunjukkan bahwa putik R. japonicus lebih dahulu masak daripada benang sarinya (protogyny). Pada tumbuhan ini terjadi ketidakcocokan silang sendiri (self-incompatible). Tumbuhan ini tidak mengalami penyerbukan sendiri (selfing) dan juga tidak membentuk biji tanpa pembuahan (agamospermy), tetapi melakukan penyerbukan silang (out-crossing) dan membutuhkan perantara (pollinator) untuk pembentukan bijinya.

Kata kunci: out-crossing, protogyny, Ranunculus japonicus, self-incompatible, system reproduksi
\end{abstract}

Diterima: 24 Mei 2002, disetujui: 16 Oktober 2002

\section{Introduction}

Ranunculus is the largest genus in the family Ranunculaceae with great diversities (Tamura, 1980; Kadota, 1990). Many of them are familiar spring wild flowers in temperate regions, with an estimated 600 species distributed in all continents (Tamura, 1967), of which about 200 species are distributed in the temperate and cold regions in the world wide, mainly in Asia and Europe, about 80 species in mainland of China, 11 species in Taiwan (Yang \& Huang, 1996) and more than 26 species in Japan (Ohwi \& Kitagawa, 1983).

$R$. japonicus is belonging to sect. Acris which distributed in wide-range in Japan (Hara \& Kurosawa, 1956; Ohwi \& Kitagawa, 1983). The basic chromosome number of $R$. japonicus is $\mathrm{x}=7$ (Hara \& Kurosawa, 1956; Kurita, 1966; Goephert, 1974). Based on the karyological evidence, Hara and Kurosawa (1956) presumed that $R$. japonicus is the ancestor of some species of sect. Acris in Japan. If Hara and Kurosawa's (1956) presumption is true, $R$. japonicus played important role for evolutionary of Ranunculus in Japan.Analysis of breeding system is an important step for understanding the evolutionary process, genetic diversity of populations or species (Sutar et al., 2000), and conservation process (Richard, 1996).

In general, outcrossing species usually contain high genetic diversity within population or species, and less genetic divergence among populations (Hamrick \& Godt, 1990; Richter et al., 1994), whereas selfing species consist of uniform individuals genetically and have substantial level of genetic divergence (Affre et al., 1997; Maki et al., 1999). Thus, to understand the genetic diversity of populations, how this species reproduct next generations should be investigated. For this reason, I carried out crossing test to clarify breeding system of $R$. japonicus.

\section{Materials and Methods}

Observations of floral behavior of $R$. japonicus

Observation of floral behavior were carried out at Botanical gardens Osaka City University using 150 flowers of 43 individuals 
collected from Mt. Ontake, Nagano Pref. and Mt. Ibuki, Shiga Pref., Japan. R. japonicus is a perennial herb, with bright yellow, radical shape flowers on a compound cymoses inflorescences. The flower consist 5 sepals, 5-7 petals with a nectary at the base, many stamens and many free carpels with one ovule.

The flowers were numbered and the condition of petals and stamens were observed daily at 7.00 a.m., 10.00 a.m., 12.00 a.m., and 3.00 p.m. Receptivity of stigmatic area was examined by following procedure. Flower buds were bagged. Flower or flower buds were fixed with FAA (formaldehyde : acetic acid : $50 \%$ ethanol $=5: 5: 90)$ after 4 hours from handpollinated. They were soak in $1 \mathrm{~N} \mathrm{NaOH}$ about 8 hours and stained $0.1 \%$ anilin blue solution in $0.1 \quad \mathrm{~N} \quad \mathrm{~K}_{2} \mathrm{PO}_{4}$ and observed with the fluorescence microscope (Martin, 1958). If pollen tube grew, stigmas were judged as on the phase receptivity.

\section{Breeding tests}

To examine breeding system (whether $R$. japonicus is sexual reproduction or agamospermy, producing seed without sex); self-compatible or self-incompatible; autogamy or xenogamy), crossing test were performed as follows: 1). Control, the flowers were left in natural condition; 2). Bagging, the flowers were bagged with a nylon mesh bag $(50 \mathrm{~mm}$ diameter) before anthesis; 3). Emasculation, before anthesis all stamens were emasculated and bagged; 4). Self-pollination, stigmas were pollinated with the pollens from the same individual; 5). Cross-pollination, stigmas were pollinated wit the pollen from different individuals in the same population (Crosspollination 1) and different population (Crosspollination 2).

After three weeks from treatment fruit were harvested. Frequency of seed set was estimated as number of fertile achenes per total achenes in a head. Fertile Achenes are characterized by rather swollen and more bigger achenes and contain endesperm in the seed.

\section{Results and Discussions}

\section{Results}

$R$. japonicus started anthesis at 10.00 a.m.12.00 a.m. and closed at about 3.00 p.m. until 5.00 p.m. Petals continued to open in the morning to midday and close in the evening for 3 to 4 days (Fig. 1. Sepals became recurved at noon of the first day and did not close again. At the third to fourth morning the petals reopened but did not close in the evening. Sepals dropped at fifth to sixth day and all petals dropped on the sixth to seven day. The stamen are arranged in five whorls. About one hour after petals opened on the first day of anthesis, the outer stamens began dehisced. The remaining stamens dehisced successively until the fourth to fifth day. In the fifth to seventh evening, all pollen grains within stamens appeared to have been dispersed. Stigmatic area has been receptive 12 hours before anthesis and continued for about the following fifth to seventh day judging from observations of pollen grain germination (Fig. 2). These observation indicated that $R$. japonicus is protogynous. Crossing test were carried out to examine self-incompatibility of $R$. japonicus. The fact that emasculation test resulted in $0 \%$ seed set (Table 1) and indicated no possibility of agamospermy in $R$. japonicus. Seed set of cross pollination 1 and 2 were $75 \%$ and $91 \%$, respectively (Table 1). The low seed set resulted from self pollination showed that $R$. japonicus was almost self-incompatible.

\section{Discussions}

Plant breeding system and mode of pollination have been identified as a major factor influencing genetic diversity and population structure of populations (Hamrick and Godt, 1990; Akimoto et. al. 1998). It is generally to say that out-crossing plant species has higher level of genetic variations than selfing species (Hamrick et. al. 1979; Hamrick and Godt, 1990). Hence, breeding system of the $R$. japonicus must be recognized before assessing its genetic variation.

The result of observations concerning floral behavior and flowering phenology of $R$. japonicus clearly showed that this species perform dichogamy and protogyny. Dichogamy, 
the phenomenon that timing of anther's dehiscence shifts from stigma's receptivity, is a important factor of breeding system which generally assumed to be an adaptation to prohibit self-pollination and promote crosspollination (Proctor et. al., 1996). The Stigmas have already been receptable pollens at the flowers buds stage when anthers still do not dehisce (Fig.1). Protogyny is also found in $R$. acris (Wyatt, 1983).

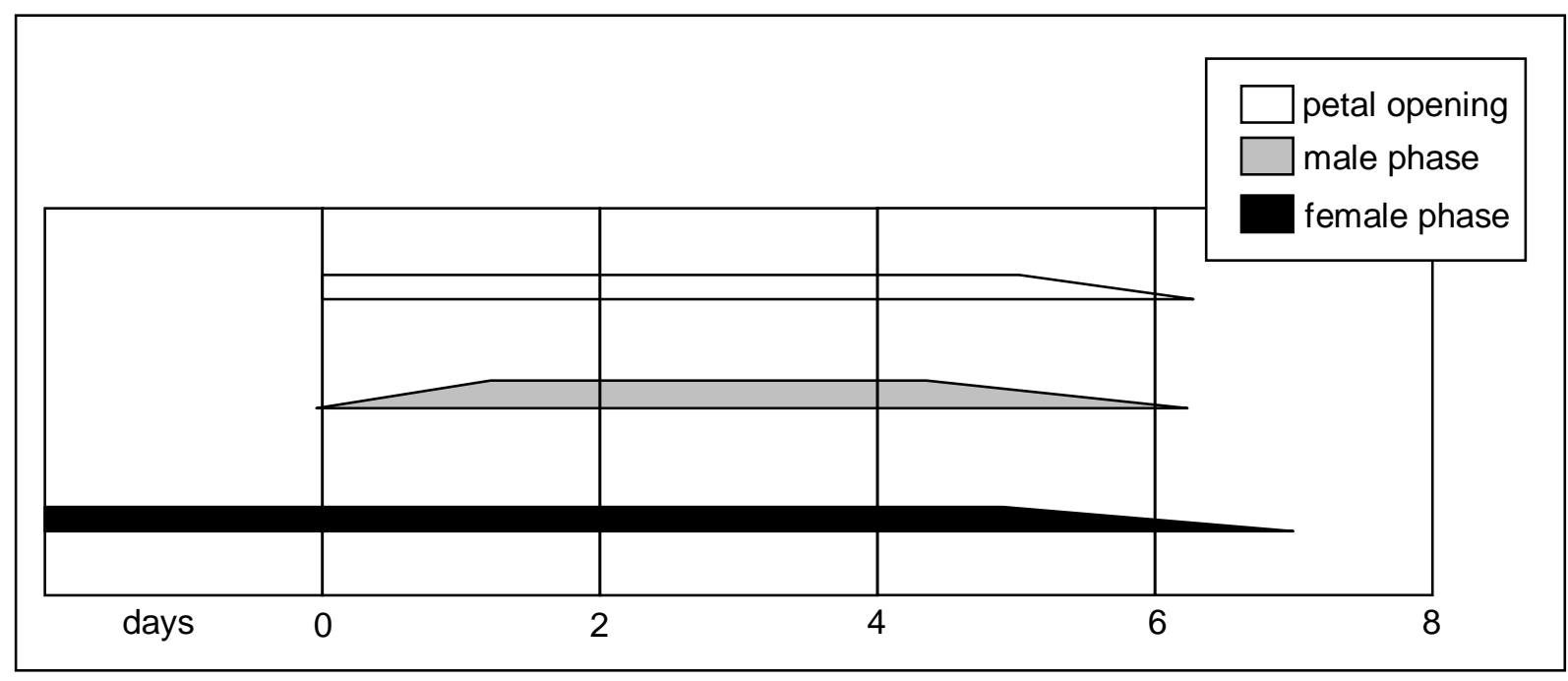

Figure. 1. Floral behavior of Ranunculus japonicus. 0 at $x$ axis: 0 a.m. at the first day anthesis. Oblique line: the possibility of beginning or finishing time of petal movement, pollen exclusion and/or stigma receptivity

Table 1. Results of crossing test in R. japonicus

\begin{tabular}{clcc}
\hline No. & Treatment & Number of sample & Seed set (\%) Mean \pm SD \\
\hline \hline 1 & Control & 47 & $47.9 \pm 28.5$ \\
2 & Bagging & 25 & $0 \pm 0$ \\
3 & Emasculation & 20 & $0 \pm 0$ \\
4 & Self-pollination & 16 & $7.1 \pm 18.7$ \\
5 & Cross-pollination 1 & 22 & $75.0 \pm 24.0$ \\
6 & Cross-pollination 2 & 20 & $90.9 \pm 11.5$ \\
\hline
\end{tabular}




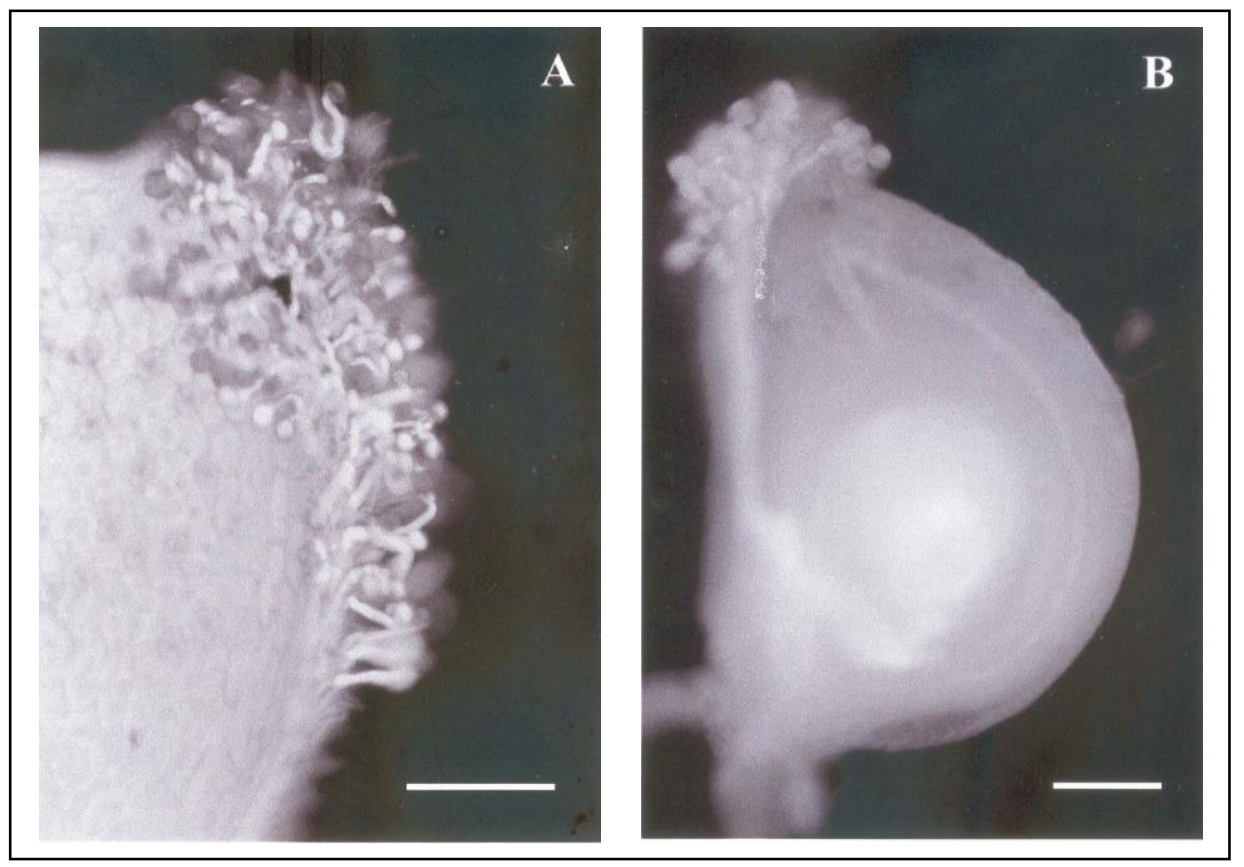

Fig. 2. Fluorescence microphotographs of stigmatic area of Ranunculus japonicus.

Bar: $200 \square \mathrm{m}$. A: Numerous pollen tubes germinated on stigmatic area. B: Pollen tubes grew toward embryo.

Further, $R$. japonicus was selfincompatible and out-crossing, judging from the results of crossing test (Table 1) and field observation of flower visitors. Selfincompatibilty is also known from R. acris (Osterbye, 1977). Moreover, floral characters of $R$. japonicus, such as; many flowers, rotate corolla, numerous stamens, anthers do not dehisce in the bud, stigma receptivity and anthers dehiscence asynchronous, many ovules per flower, nectar present etc (Ornduff, 1969; Wyatt, 1983), and strong UV absorption of all part of flowers (Utech and Kawano, 1975) indicated that this species is complete outcrossing species and expected to maintain a higher genetic diversity (Hamrick and Godt, 1990). It is clarified that $R$. japonicus has a higher level of genetic diversity (Syamsuardi, 2002; Syamsuardi and Okada, 2002) than other plants with similar reproductive and phytogeographical traits (Hamrick and Godt, 1990).

\section{Conclusions}

Judging from the observation of floral behavior and results of breeding test, I concluded that : 1). R. japonicus exhibited protogyny and self-incompatible. 2). There is no possibility of spontaneous autogamy (selfing) in $R$. japonicus, and pollen vectors are required for seed set. 3). $R$. japonicus performs out-crossing for its seed production.

\section{Acknowledments}

I deeply grateful to my supervisor, Prof. H. Okada, for his advice and encouragement during the study. We also sincerely grateful to Dr. Y. Mori and Dr. A. Takano for their critical discussions, to Dr. M.N. Tamura, Dr. J. Yamashita, and Ms. S. Fuse for their help in obtaining plant materials. This study was partly supported by Nippon Life Insurance Foundation $(1998,1999)$ and was part of the DSc. dissertation research at Graduate School of Science Osaka city University. 


\section{References}

Affre, L., J. D. Thompson, and M. Debussche, 1997. Genetic Structure of Continental and Island Populations of Mediterranian Endemic Cyclamen balearicum Primulaceae. Amer. Jour. Bot. 84: $437-$ 451.

Akimoto, M., Y. Shimamoto, and H. Morishima. 1988. Population of Genetic Structure of Wild Rice Oryza glumaepatula Distributed in the Amazon Flood Area Influenced by its Lifehistory traits. Mol. Ecol. 7: 1371-1381.

Goepfert, D. 1974. Karyotype and DNA Content in Species of Ranunculus L. and Related Genera. Bot. Not. 127: 464-489.

Hamrick, J.L., H. Linhart and J.B. Mitton. 1979. Relationship Between Life Story Characteristic and Electrophoretically Detectable Genetic Variation in Plant. Ann. Rev. Ecol. and Syst. 10: 173-200.

Hamrick, J.L. and J.W. Godt. 1990. Allozyme Diversity in Plant Species. In Brown, A.H.D., Clegg, M.T., Kahler, A.L. and Weir, B.S. Eds. Plant Population Genetics, Breeding and Genetic Resources, 43-63. Sinauer, Sunderland, M.A.

Hara, H. \& S. Kurosawa. 1956. Cytotaxonomical Notes in the Ranunculus acris Group in Japan. Bot. Mag.Tokyo 69: 345-352.

Kadota, Y. 1990. Taxonomical Notes on the Alpine Species of Ranunculus in Japan. Bull. Nat. Sci. Museum, Tokyo, Seri B, $18: 73-92$.

Kurita, M. 1966. Chromosome Studies in Ranunculaceae XXIV. Memoirs of the Ehime University Section II Science, Seri B Biology 5: 103-108.

Maki, H., M. Morita, S. Oiki and H. Takahashi. 1999. The Effect of Geographic Range and Dichogamy on Genetic Variability and Population Genetic Structure in Trcyrtis Section Flavae Liliaceae. Amer. Jour. Bot 86: 287-292.
Martin, F.W. 1958. Staining and Observing Pollen Tubes in the Style by Means of Fluorescence. Stain Tech. 34: 125.

Ohwi, J. and M. Kitagawa. 1983. New Flora of Japan. Pp. 688-696. Tokyo: Shibundo Co.,Ltd. Pubs. In Japanese.

Okada, H. and M. Tamura. 1977. Chromosome Variations in Ranunculus qualpaertensis and Its Allied Species. Jap. Jour. Bot. 52: 360-369.

Ornduff, R. 1969. Reproductive Biology in Relation to Systematics. Taxon 18: 121123.

Osterbye, U. 1977. Self-incompatibility in Ranunculus acris L. II. Four S-loci in a German Population. Hereditas 87: 173178.

Proctor, M., P. Yeo and A. Lack. 1996. The Natural History of Pollination. Timber Press. Portland. 479 pp.

Richard, A.J. 1997. Plant Breeding Systems. $2^{\text {nd }}$ Ed. Chapman and Hall London. 529 pp.

Richter, T.S., P.S. Soltis and D.E. Soltis. 1994. Genetic Variation within and among Populations of the Narrow Endemic, Delphinium viridescens Ranunculaceae. Amer. Jour. Bot. 81: 1070-1076.

Suter, M. , J. J. Schneller and J. C. Vogel. 2000. Investigations into the Genetic Variation, Population Structure, and Breeding System of the Fern Asplenium trichomanes subsp. Quadrivalens. Int. Jour. Pl. Sci. 161: 233-244.

Syamsuardi 2002. Genetic Diversity, Population Structure of Populations of Ranunculus japonicus Thunb., Ranunculaceae. Pl. Spec. Biol. 17: accepted and will be published.

Tamura, M. 1967. The Morphology, Ecology and Evolution of Ranunculaceae. Part 7. Sci. Rep., Coll. Gen. Educ., Osaka Univ. 16: 21-43.

Tamura, M. 1980. Systematic Part, Ranunculoideae $7 . \quad$ Ranunculeae. Pflanzenfamilien. Bd. 17a IV: 412-433. 
1970. Ranunculus subsect. Acres of Japan and Neighboring Areas. Acta Phytotax. Geobot. 24: 153-167. In Japanese.

Utech, F.H. and S. Kawano. 1975. Spectral Polymorphism In Angiosperm Flowers Determined by Differential Ultraviolet Reflectance. Bot. Mag. Tokyo. 88: 930.Press, London.

Wyatt, R. 1983. Pollinator-plant Interaction and the Evolution of Breeding system. In Real, L. Ed. Pollination Biology. 51-95. Academic Press, London.
Yang, T.Y. A. and T. C. Huang. 1996. Additional Remarks on Ranunculaceae in Taiwan. Some genera in Taiwan. Taiwania 41: 117-153.

Syamsuardi and H. Okada. 2002. Genetic Diversity and Genetic Structure of Ranunculus japonicus Thunb., Sect. Acris, Ranunculaceae, and Its Genetic Relationships to Relative Species in Japan. D.Sc. Thesis, Osaka City University, Osaka, Japan. 